\title{
Pegylated Recombinant L-asparaginase Erwinia chrysanthemi
}

National Cancer Institute

\section{Source}

National Cancer Institute. Pegylated Recombinant L-asparaginase Erwinia chrysanthemi.

NCl Thesaurus. Code C101259.

A pegylated, recombinant form of L-asparaginase derived from the bacterium Erwinia chrysanthemi (mPEG-R-Crisantaspase), with potential antineoplastic activity. Upon intravenous administration of pegylated recombinant L-asparag inase Erwinia chrysanthemi, asparaginase hydrolyzes L-asparagine to L-aspartic acid and ammonia, thereby depleting cancer cells of asparagine thus blocking protein synthesis and tumor cell proliferation. Asparag ine is critical to protein synthesis in cancer cells, which cannot synthesize this amino acid due to the absence of the enzyme asparagine synthase. Compared to other available Erwinia chrysanthemi derived L-asparaginase agents, the pegylated form is longer acting and less immunogenic. 